\title{
Politics and the Humanistic Pose: David Hare's Wall
}

\author{
Bahareh Azad ${ }^{*}$, Hossein Pirnajmuddin ${ }^{* *}$ \\ Department of English Language, Faculty of Foreign Languages, University of Isfahan, \\ Daneshgah Street, Azadi Square - 8174673441, Iran \\ *,**E-mail address: baharazad125@gmail.com , pirnajmuddin@fgn.ui.ac.ir
}

\begin{abstract}
Colonialism is not best understood primarily as a political or economic relationship that is legitimized or justified through ideologies of racism or progress. Rather, colonialism has always, equally importantly and deeply, been a cultural process; its discoveries and trespasses are imagined and energized through signs, metaphors and narratives; even what would seem its purest moments of profit and violence have been mediated and enframed by structures of meaning. Colonial cultures are not simply ideologies that mask, mystify or rationalize forms of oppression that are external to them; they are also expressive and constitutive of colonial relationships in themselves. (Thomas 1994, 2)
\end{abstract}

\begin{abstract}
David Hare has tried his hand at 'writing history' for the East in a number of plays. In Wall he is keen on conferring an aura of historicity on his personal account, one thinly masked by the manipulation of documentary drama or verbatim theater as theatrical medium. Having promised to deliver an objective, impartial, and 'liberal' study of the Middle East, and aware of the accusations his 'First World' position before the Eastern subject (object) may bring against him, Hare arduously strives to avoid hackneyed representations of the unprivileged. Yet, he turns out to have fallen prey to that same old trap of polarizing and stereotyping. However, this "historigraphic metadrama" is often treated as having 'authenticity.' Hence, the writers in this paper aim at exploring the Western unilateral fixations of the East behind the façade of humanistic treatment in the playwright's historiographic approach.
\end{abstract}

Keywords: David Hare; Wall; postcolonial studies; liberal humanism; orientalism; historiographic rewriting

\section{ORIENTALISM AND THE HUMANITIES}

Orientalism's scholarly stature has been radically questioned by Edward Said. To him, Orientalism is a "Western style for dominating, restructuring, and having authority over the Orient" (Said 2003, 4). Orientalism as defined by Said is "the enormously systematic discipline by which European culture was able to manage - and even produce - the Orient politically, sociologically, militarily, ideologically, scientifically, and imaginatively during the postEnlightenment period" (p. 4). 
The interdependence of Orientalism and "pedagogy" Said reminds us as "the dynamic between scholarship and imaginative writing" (p. 24), illustrates humanism's stress on the motif of art and thus literature and writing. The problem, however, is that "the general ethnocentricity and cultural myopia of the Humanities," in Aijaz Ahmad's words $(1987,77)$ cooperate in perpetuation of the colonial tragedy.

In return, as Chambers puts it, "[t]he postcolonial operates an incision on the existing corpus of knowledge, and most precisely in the humanities" $(2001,22)$. As such, opposing the arrogance of humanism, whose "pretensions of reason" bring about nothing but a foppish liberalism, revisionists find fault with its "dream of power" and lust for "control" (Ehrenfeld 1981, 253). In simple words, they recognize an easy coexistence between the colonial discourse and the potentiality of writing; the ideology-saturated writing of an author, bombarded with the governmental apparatuses of control would act - even if involuntarily - as the state's invisible weapon against its opponents, inside and out of borders (Fairclough 1989, 36). Most notably, "Postcolonial theory's suspicion of Western narratives of enlightenment and progress" stems from their ingrained "imperial ideology and mission" (Li 2005, 213), aspiring "not only to conquer other parts of the world for their economic resources but to submit them also to the civilizing effects of Western literature and culture" (Habib 2008, 226).

\section{LIBERAL HUMANISM AND POSTCOLONIALITY}

The influence exerted by the Enlightenment's notions of rationality, progress, reason, and objectivity, along with liberal principles of liberty, autonomy, and tolerance fabricated the binarisms of rational/irrational, developed/backward, and white/non-white which entrenched epistemological demarcations between the Occident and the Orient.

Drawing on Foucault's ideas, Edward Said observes:

There are a number of features which occur again and again in texts about colonized countries and that these cannot be attributed simply to the individual author's beliefs, but are rather due to large-scale belief systems structured by discursive frameworks, and are given credibility and force by the power relations found in imperialism. $(1983,106)$

In a similar fashion David Hare's political ideology as a liberal humanist advocate (Boon 2007, 65), can be analyzed in the light of Bhabha's declaration that, "[ $t]$ he textual process of political antagonism initiates a contradictory process of reading between the lines; the agent of the discourse becomes, in the same time of utterance, the inverted, projected object of the argument, turned against itself" (quoted, Huddart 2006, 16). Being the "agent of the discourse" or a "political actor," Hare, it is argued, becomes a "split subject," devoid of transparent and honest claims "without division or doubt," whose "ambivalent" liberal support of the East turns against himself (p. 16). The philosophy of liberal humanism, consequently, sets Hare's point of departure from look-back-in-anger generation of radical playwrights; "[l]ooking forward with no anger" (Boireau 2003, 29) describes well enough his new orientation. The Establishment, of course, awarded Hare for this watershed change in attitude and career by conferring on him its ultimate symbol. It is, then, Sir David Hare who allegedly tries to make sense of 'Israeli-Arab crisis' in the Middle East in works such as Via Dolorosa and Wall. 
Having been proposed to be "a passionate and unrelenting critic of the establishment and of what we may call "the official culture" (Boon 2003, 1), Hare takes "Britain's moral temperature" by means of "occasional excursions into the Third World" (Bull 1984, 2). To be more precise, applied as a rough draft of liberal humanist theories for the required political amendments to his homeland's governmental system, the 'Third World,' specifically the Middle East in the case of Wall, has been laid open to Hare's analytical surgery.

\section{WALL}

Wall (2009) is David Hare's account of the construction of a wall around Israeli borders, years after his first trip and its record in his Via Dolorosa (1998): "Please, please: consider the state of affairs, consider the desperation, consider the depth of the despair. A country has reached a point at which eighty-four percent of its people are in favor of building a wall along its borders" $(2009,29)$.

Objective as he claims to be, Hare turns to the verbatim theater - "interview-based plays," even if not taken "word-for-word from the actual interviews" (Hayes 2004, 86) - in order to represent both sides of the dispute on equal scales of a documentary judgment. Interestingly, verbatim plays' creators, cast in the role of "oral historians," are supposed to recount the reality of the current events under examination (p. vii). However, like Via Dolorosa, Hare's earlier documentary drama, Wall which partakes in its "varying degrees of self-reflexivity between the reporting mode of verbatim drama and personal commentary" (Berninger and Henke 2011, 5) discloses much of the dramatist's personal attitude towards the Eastern conflict. Indeed, being treated as a political pamphlet rather than a literary work, taking advantage of literary devices and dramatic techniques, Wall turns into the dramatist's liberal mantra in which Hare protagonist plays the know-all conciliator.

In point of fact, the invalidity of Hare's assertion that " $[\mathrm{t}]$ he one thing that Via Dolorosa has is no opinions" (quoted, Wroe 1999, 57) is underscored by virtue of his personal impressions of or intermittent responses to the debates and incidents in both plays. Unsurprisingly then, stripped of its critical edge, Hare's liberal pleas fail to meet their pledge of impartiality and detachment; justice is not Hare's strong point, to say the least.

By way of an example, although the play asserts: "The Berlin Wall was built to keep people in. This one, they say, is being built to keep people out" (Hare 2009, 29), it never seriously questions the building of the latter. Nevertheless, reduced to a "they"-said narrative and, therefore, negated owing to its fictitious make-up, the wall in Palestine/Israel is transformed into the symbol of protection, and not of confinement.

Wall appears to be informed by the Western dominance of wisdom over the Eastern theme of conflict. Playing the impartial observer role and monitoring the uplifting of Jerusalem on account of a wall project at Eastern hands, Hare laments the lost spirituality of Western civilization's birth place. It seems as if, in his eyes, the Israelis' marring of the city's beauty by the construction of a wall is a much more unforgiveable crime than its being an attempt at "racial segregation" (p. 30). Accordingly, Hare's pose of idiocy is merely a satiric rebuke of the Easterners' uncivilized lack of a sense of beauty:

Am I just a decadent Westerner who can't help thinking spirituality must have something to do with beauty? Am I the only idiot who still confuses religion with aesthetics? Oh, I see, was the whole Renaissance just a European detour, a historical mistake, an irrelevance? Jerusalem used to be beautiful. Now it isn't. ... But does that matter? What's my complaint exactly? That things are 
insufficiently medieval? As far as I'm concerned, Jerusalem is spoilt-how can it not be spoilt? (p. 39)

Priding himself on his European aesthetic appreciation, Hare expresses his rage at an Eastern "medieval" backwardness, since bereft of the "Renaissance" as "European" awakening, Easterners are uninformed about the interconnection of spirituality and beauty.

In fact, the play's insistence on universalizing a stereotypical image of the Easterners seems to be characteristic and the framed, predefined templates for their behavior in the text are escorted by enclosed characteristics of the Middle East: "There must be a solution," Hare reflects about the wall, "[t]rouble is, this being the Middle East, and especially after the latest war, neither side agrees on what the solution is. Just as Israelis finally shrug and concede that, "After all a two-state solution is indeed inevitable"' (p. 35). Much to the reader's surprise, hence, any space for transaction of ideas or common ground has been cancelled by the extract's reductive generalization of "this being the Middle East." Therefore, "this being the Middle East" naturalizes the assumption that "neither side agrees on what the solution is". However, the excerpt reveals, the Israelis are far less " trouble"some' than their Arab counterparts. Hence, it is the Israelis who "finally shrug and concede that, "After all a two-state solution is indeed inevitable"” (p. 35).

"Liberal sensitivity to difference is a white lie," Cope observes $(1995,195)$. That is to say, as far as the topic of the East is concerned, the Self seems to adopt a charade of cognition on the one hand, to conceal its fear (of the unknown) behind a pretense of mastery over 'the Other,' and of complaint about the impossibility of knowledge on the other, which derives from an emphasis on the notion of difference to mask the lust for knowing the unknown. Likewise, Hare's dubious refutation can be taken into account as a sort of defense mechanism:

Recently, I found myself writing about Berlin because I don't understand it. Now I want to write about Israel/Palestine because I do. No, hold on, let me rephrase, that's a preposterous claim, nobody understands the Middle East-but put it this way: I recognize it. It answers to something in me. (Hare 2009, 40)

What leads Hare to this hasty remark on understanding what in the West has come to be termed the Israeli/Arab crisis is his recurrent anxiety of non-partisanship: "If I use one phrase or another, forgive me. It does not imply I am partisan" (p. 30); never mind if the claim that "nobody understands the Middle East" is no less "preposterous". And more bitterly, one cannot help but be tempted to see this "nobody" as a white bourgeois male, the "universal self" (Good 1996, 88). The good news, even though, is that this anxiety at least distinguishes him from some other Western writers, in whom being "partisan" causes no sense of unease.

Markedly, Hare's disdain for a supposed Oriental ignorance is more scathing when aimed at Palestinians, which is justifiable, regarding the fact that "race is always an issue of Otherness that is not white" (Hooks and West 1991, 54). Endowed with a putative historical and biblical espousal, Israelis, further, relish the ancient "sign of privilege," namely, whiteness, by which they are provided with "a history, identity, and superior essence" (Ferber 1998, 146). Blessed for their whiteness and adaptability to Western life style, accordingly, Israelis find the chance to be excluded from the Oriental category. It comes as no surprise, then, that Hare and his English companion "zooming away with white faces and two British passports" assume the same Israeli "priority" over the non-white Arabs in 'Israel' (Hare 2009, 44), an honor which is tantamount to Via Dolorosa's "the glory of happening to be British" $(1998,6)$. 
By contrast, coming across a poster of Saddam Hossein in Nablus's most famous café, the protagonist is appalled by the Arabs' choice of their national hero: "If you were going to choose a hero," Hare interrogates, "could you choose a worse? If you were going to choose a future, could you so completely misconceive it? If you were going to choose a leader to take you precisely nowhere, could you do better than Saddam Hossein" $(2009,42)$ ?

In a nutshell, Western dogmatic control of standards and criteria allows for expounding the characteristics of terrorism, terrorist, and even the Other's response to this interpretive mechanism. Partaking in the Western theory of With-Us-Or-With-Terrorists, Hare wonders "Hossein stood for everything Hamas doesn't. Secularization. A non-religious state. Have they thought about that? Let alone his matchless record for killing Arabs" (p. 42).

Simplifying Arabs' hatred of American policies by foregrounding their "dumb" theory of "[m]y enemy's enemy is my friend" (p. 43), the play accentuates Palestinians' purported political ignorance, immature philosophy, and low standards of thought: "Well Saddam stood up to the Americans, didn't he? ... We hated Saddam Hossein like everyone else. We despised him.

We couldn't stand him. But then he stood up to the Americans" (p. 43). Here, the implication is that Palestinians, who are incapable of sane principles, may fall prey to any vicious criminal as leader, should they be left to their own accord. Due to its adherence to a tradition of reducing Arabs to mindless radicals, who are prone to any idiocy even at the expense of their own most fundamental codes of honor because of their blind hatred of America, the play fails to stand away from the impeialist discourse shaping the British Hare. Further, as Threadgold points out about perpetuation of such discourses:

these identity - and reality-constructing discourses and genres, dialogism and debate, are constantly remade, rewritten and recontextualised by differently positioned writers and readers across a range of genres produced in a diversity of institutional sites and in relation to complex networks of knowledges and reading and writing practices. $(1997,136)$

Put differently, a piece of writing's internalization of a biased hypothesis in the reader's mind is actualized, gradually, by means of its frequent textual insertion. As a consequence, that assumption being peeled off of its odd garment comes to seem as normal via a process of naturalization. For this reason, when Western natural supremacy over the East is inculcated the reader's taste grows accustomed to more oddities each time and a progressive sense of believability substitutes the logic of resistance.

This being the case, the play's prejudices like, "[t]he rise of Hamas scares the shit out of every one" (p. 36) or the presumed accounts of Hamas's tortures (p. 37) are welcomed as normality without contemplating the fact that, being the product of the democratic concept of election, "Hamas was elected in Gaza in January 2006" (p. 33).

\section{CONCLUSION}

Hare's unbending criticism of English institutions at home in plays such as Murmuring Judges, The Permanent Way, Racing Demon, to mention a few, can hardly be extended to overseas concerns. As far as the confrontation of the East and the West is the case, the inferiority of the former to the latter goes without question. Elevating the Western outlook to 
the detriment of the Palestinian one, the play shuts out the Other's evaluation of its own state of affairs.

The fact that Hare, a metropolitan intellectual, casts doubt on the absolutism of the center's assumptions should not veil the undesirable reality that his comfortable stance on liberal humanist discourse, along with his 'natural' Western superiority needs to be examined in terms of the power relations at work in the production of his works addressing the peripheral Eastern subject. In other words, Hare's liberal contribution to the mainstream procedures of value formation via standardization of cultural, social, ethical, and ideological codes and their application to the humanities as the nucleolus of intellectual orientations appear to be capable of giving the world powers enough room for political maneuver and exploitation of the unprivileged. Accordingly, the appraisal of his ideological principles, embedded in Wall, reveals how Hare ultimately subscribes to the West's dominant outlook towards the contemporary Middle East.

\section{References}

[1] Ahmad Aijaz, Social Text 17 (1987) 3-25.

[2] Berninger Mark, Christoph Henke, European English Messenger 20(1) (2011) 81.

[3] Boireau Nicole, European Journal of English Studies 7(1) (2003) 25-37.

[4] Boon Richard, The Cambridge Companion to David Hare. Cambridge: Cambridge UP, 2007.

[5] Boon, Richard, About Hare. London: Faber and Faber, 2003.

[6] Bull John, New British Political Dramatists: Howard Brenton, David Hare, Trevor Griffiths, and David Edgar. New York: Grove Press, 1984.

[7] Chambers Iain, Culture After Humanism: History, Culture, Subjectivity. London: Routledge, 2001.

[8] Cope B., RePublica 2 (1995) 182-206.

[9] Ehrenfeld David, The Arrogance of Humanism. Oxford: Oxford U P, 1981.

[10] Fairclough Norman, Language and Power. London: Longman, 1989.

[11] Ferber Abby L., White Man Falling: Race, Gender, and White Supremacy. Lanham: Rowman \& Littlefield, 1998.

[12] Good Graham, Canadian Literature 148 (1996) 75-91.

[13] Habib Rafey, Modern Literary Criticism and Theory: A History. Massachusetts: Blackwell, 2008.

[14] Hare David, Via Dolorosa \& When Shall We Live? London: Faber and Faber, 1998.

[15] Hare David, The Permanent Way. London: Faber and Faber, 2002.

[16] Hare David, Berlin/Wall. London: Faber and Faber, 2009.

[17] Hare David, Murmuring Judges. London: Faber and Faber, 1991.

[18] Hare David, Racing Demon: A Play. London: Faber and Faber, 1989. 
[19] Hayes Stephen F., The Connection: How al Qaeda's Collaboration with Saddam Hussein Has Endangered America. London: Harper Collins, 2004.

[20] Hooks Bell, Cornel West, Breaking Bread: Insurgent Black Intellectual Life. Boston: South End Press, 1991.

[21] Huddart David, Homi K. Bhabha. London: Routledge, 2006.

[22] Li Victor, "Toward Articulation: Postcolonial Theory and Demotic Resistance." In Linked Histories: Postcolonial Studies in a Globalized World (209-228), eds., Pamela McCallum, Wendy Faith. New York: U of Calgary P, 2005.

[23] Said Edward, Orientalism. London: Penguin, 2003.

[24] Thomas Nicholas, Colonialism's Culture: Anthropology, Travel and Government. Oxford: Polity Press, 1994.

[25] Threadgold T., Feminist Poetics: Poeisis, Performance, Histories. London: Routledge, 1997.

[26] Wroe Nicholas, "The Guardian Profile: David Hare, Makeover Artist." Guardian, $<\mathrm{http}$ ://books.guardian.co.uk/departments/artsandentertainment/story/0,103076,00.html $>$ 